\title{
Publisher Correction: Dimensions of Parenting Stress as Predictors: Vocabulary and Phonological Awareness Skills in Preschool
}

\section{Dilara Deniz Can $\mathbb{1}^{1} \cdot$ Marika Ginsburg-Block ${ }^{2}$}

Published online: 9 September 2021

(c) Springer Science+Business Media, LLC, part of Springer Nature 2021

Correction to: Journal of Child and Family Studies https://doi.org/10.1007/s10826-021-02010-5.

The original version of this article that appeared online early July of 2021 did not reflect author updates that the publisher failed to incorporate. The original article is being published online in September 2021 with errors corrected. This version replaces the earlier one.

The original article has been corrected.

The original article can be found online at https://doi.org/10.1007/ s10826-021-02010-5.

\footnotetext{
Dilara Deniz Can

dilaradenizcan@gmail.com

$\triangle$ Marika Ginsburg-Block

marika@udel.edu

1 School Psychologist III, Cherokee County School District (via Soliant Health), 141 Twin Lake Road, Gaffney, SC 29341, USA

2 University of Delaware, College of Education and Human Development, 206B Willard Hall Education Building, Newark, DE 19716, USA
} 